\title{
RUSSIA'S ECONOMY IN JUNE 2013: PRELIMINARY DATA AND PRINCIPAL TRENDS
}

\author{
K.Rogov
}

Socio-political environment. June 2013 was relatively quiet, but its major events were triggered by recently accumulated political conflicts and confrontations.

Having denied in May an option for economic amnesty proposed by the business community, President Putin offered his own version in June: not only does Putin's version rule out any possibility to include $M$. Khodorkovsky in the amnesty, it also specifies compensation for damages as compulsory condition for amnesty. This is a symbolically important update: according to the business community, the amnesty should have been an act of state's recognition of inadequate application of the criminal law against entrepreneurs, whereas in Putin's version it becomes an act of grace towards those who acknowledged the jail sentence legitimacy, i.e. the repressive rule of law established against businesses.

The 2013 Moscow mayoral election campaign and the conflict between President Putin and the Russian Academy of Sciences (RAS) were most high-lighted political events. Immediate electoral threats were minimized for S. Sobyanin (such hypothetic threats could have been created by communist union candidate Melnolkov, systemic opposition member M. Prokhorov, and non-systemic figure in opposition A. Navalny) after M. Prokhorov refused to run for mayor of Moscow, and Sobyanin's headquarters are basically focused on making his potential winning look legitimate as much as possible. The opposition has found itself under unfavorable conditions due to lack of time and monies to mount an effective election campaign against Sobyanin, as well as A. Navalny is being involved in a lawsuit against him in Kirov.

The proposed version of the reform of the Russian Academy of Sciences (RAS) is reduced to depriving RAS of the right to dispose of its property and assets. Externally, this version of the reform has been comprehended as Putin's response to the election of academician Fortov as RAS president and non-election of M. Kovalchuk, who is considered being close to President Putin, as director of the RAS-affiliated Institute of Crystallography.

Furthermore, President Putin's proposal to unite the Supreme Court and Supreme Arbitration Court of Russia looks like an echo of political confrontations. This significant reform, which requires amendments to the
Constitution of the Russian Federation, is unmotivated and according to experts and general public is only intended to create the position of chairperson in the united supreme court for incumbent Prime Minister Dmitry Medvedev after his alleged resignation soon.

An important event in June was the arrest of Makhachkala mayor Said Amirov which looked like a military operation. S. Amirov was a key figure who governed political balance in Dagestan and the North Caucasus in general. His arrest by special forces and transfer to Moscow must instate the Kremlin in its right to arrest selected regional leaders, on the one hand, and strengthen the position of Moscow's appointee Ramzan Abdulatipov as President of Dagestan, on the other hand. The situation in Dagestan has become essential due to upcoming Olympic games in Sochi.

Macroeconomic environment in June was governed by the events in external markets and Russia's economy sliding towards stagnation as evidenced by the May economic statistics. External adverse environment was governed by global markets' nervous response to the US economic authorities' statement about intentions to discontinue FRS's quantitative easing programs (the statements sounded more relaxed at the end of the month), as well as the problems in the Chinese banking system. Crude oil prices fluctuated within established corridor (Brent crude oil of \$100-106 p/b) as non-ferrous metals lost in price (a decline of about $10 \%$ on average). As a result, the MICEX index lost $11.5 \%$ from May 22 to June 13, 2013, but both global and Russian stock markets saw correction at the end of the month after a sedative FRS meeting and amid growth in crude oil prices. As a result, the MICEX index dropped about 2\% at the end of June 2013.

Weakening of a ruble exchange rate became a more important macroeconomic factor, which analysts consider as soft devaluation. The weakening followed Minister of Finance's statements about potential weakening of a ruble exchange rate which triggered markets' nervous response. In general, the ruble began to weaken since April 2013: the USD gained 8.3\% over $R U B$ (from $R b 30,19$ to $R b 32,71$ as of June 29, 2013), a the dual currency basket lost 6.3\%, in June RUB lost $3.5 \%$ again USD, and the dual currency basket lost 3.9\%. The Russia's Government wants the ruble to weaken indeed: federal budget revenues accounted 
for $20.0 \%$ of GDP in January-May (against 22.2\% year on year) in response to deteriorated global prices and rapid slowdown in economic growth rates. In addition, US monetary authorities' intention to discontinue bond redemption programs is likely to force down crude oil prices in the upcoming fall. Preventive weakening of a ruble exchange rate amid such conditions would equalize the budget and mitigate potential shocks in the upcoming fall if prices go down fast.

In June, inflation dropped from $7.44 \%$ to $6.9 \%$ on a year-on-year basis in response to a very high inflation background in June 2012 (+0.9\% of May 2012). Monthly prices grew up at a rate of $0.4 \%$ in June 2013, whereas core inflation stood at $0.3 \%$ against $0.4 \%$ in June 2012. Inflation slowed down basically in response to more moderate growth rates in prices of fruit and vegetable products and services in June 2013 against the previous year. Furthermore, it should be noted that money supply growth rates were moderate too: M2 growth slowed down on a year-on-year basis from 19.6\% as of May 1, 2012 to 15.2\% as of May 1, 2013. However, the June inflation slowdown shouldn't be confused with change in the trend: the upcoming indexation of communal services tariffs will maintain inflation.

The updated Central Bank's data on capital outflow show that the situation keeps very unfavorable. In H1 2013, net capital outflow totaled $\$ 38,4$ bn as reported by the Central Bank of Russia, $\$ 28,4 \mathrm{bn}$ in Q1 2013 (instead of previously reported $\$ 25,8 b n$ ), and \$10bn in Q2 2013.

Situation in the real sector leaves no doubt that the situation in the Russian economy can be characterized as stagnation. Improved economic figures in MarchApril gave way to their deterioration in May. The industrial sector shows negative growth rates on a yearon-year basis -98.6\% against May 2013 (manufacturing sector $-95.6 \%)$, trade turnover dropped to $2.9 \%$. In fact, annual figures improved in March-April in response to the weak data on March-April 2012, when the economy showed first signs of a serious slowdown, May 2012 was rather better. Not counting the base effect, it becomes apparent that Russia's industrial sector has been stagnating year-to-date, industrial growth rates in January-May 2013 stood at $0.2 \%$ year on year (mineral extraction industry $-0.6 \%$, manufacturing sector $-0.2 \%)$. The situation in the mineral extraction sector was governed by slow growth in crude oil production (100.4\% against January-May 2012) and reduction in the gas production sector (93\% against January-May 2012). The situation in the manufacturing sector is quite different: food production, chemical industry and certain types of construction materials saw positive growth rates, whereas negative rates were typical of light industry and machine building sector.

A negative uptrend in imports of consumer goods against downtrend in investment and intermediate goods developed early in 2013: consumer imports stood at 38\% and investment goods at 25\% Q1 2012 against $41 \%$ and $23 \%$ respectively in 2013 . This means that considerably weakened consumer demand is mostly covered with growth in imports rather than growth in domestic industrial production. Therefore, one may say that sluggish demand is not the only reason for the industrial slowdown.

Stagnation in investments developed in response both to sluggish demand and corporate financial health deterioration. Loss-making enterprises accounted for $36.5 \%$ of the economy at large (against $35.0 \%$ in the preceding year), including $45.6 \%$ of the mineral extraction sector (against $41.0 \%$ in the preceding year), $36.3 \%$ of the manufacturing sector (against $33.6 \%$ in the preceding year) and $49.9 \%$ of the transport sector (against $48.5 \%$ in the preceding year). It should be noted that both unemployment (unemployment rate stood at 5.8\% in Q1 2013 against 6.3\% in the preceding year) and average real wages (in Q1 2013-104.5\% against Q1 2012, a growth of 5.7\% in May) keep growing against rapid economic slowdown and corporate financial health deterioration. Indeed, such a situation can't help the economy recover from stagnation and opts for current consumption in prejudice of investments.

In general, capital investments in January-May 2013 stood at $99.6 \%$ and $100.4 \%$ in May year on year. In Q1 2013, capital investments dropped by 5.0\% in the segment of large and medium-sized enterprises, and grew up $7.1 \%$ in the segment of small-sized enterprises, though they halved year-on-year.

In Q1 2013, capital investments kept showing positive dynamics in the manufacturing sector $(108.0 \%$ against Q1 2012) amid a substantial fall in investments in the mineral extraction sector (88.6\%). Corporate profit-funded investments increased $153.0 \%$ against 50.6\% in Q1 2012), although in Q1 2013 profitability stood at $8.4 \%$ in the economy at large and dropped 2.3 p.p. year-on-year. In Q1 2013, direct foreign capital investments dropped $2.8 \%$ in total investments against $3.3 \%$ in the preceding year. Such a situation with investments gives up hope of recovery from stagnation in a short-term period. 